\title{
A CREATIVE PARTNERSHIP AND AN INNOVATIVE AND EFFECTIVE MULTIMEDIA ENGLISH LANGUAGE LEARNING AND TEACHING WEBSITE
}

\author{
Zhao Baobin (zhaobb@crtvu.edu.cn) \\ Richard Arridge \\ Liu Dailin \\ Fang Muzhen \\ China Central Radio and Television University, P.R. China
}

\begin{abstract}
"in2english" as an innovative and effective multimedia English language learning and teaching website came about through a creative partnership between the British Council (BC), the British Broadcasting Corporation (BBC), China Central Radio and Television University (CCRTVU) and CRTVU-Online Distance Educational Technology Limited (CRTVU-Online). As a cooperative endeavor it combines British expertise in English teaching and development of online materials with CCRTVU's knowledge and experience of the English learning environment in China as well as expertise in ICT and development of online materials. At its inception many of the website's features were innovative and cutting edge. The free website goes beyond text and makes extensive use of multimedia. Since its launch on 5th November 2002 the website has welcomed nearly 10 million unique visitors, visited 18 million times, from its target audience of business people, English teachers, young professionals and their children. During five years of development "in2english" has evolved into a highly interactive community. "myin2english", a personalized feature, helps foster the learners' participation and ventures into the world of mobile learning highlight its continuing commitment to innovation. However, it is also a time to reflect on the lessons learned about Chinese learners' attitude to online learning. A retrospective and critical approach is needed to see how far we have come, how creative and innovative we are now and how we should proceed in the future.
\end{abstract}

Key words: "in2english", multimedia, online-learning, partnership.

"in2english.com.cn" as an innovative and effective multimedia English language learning and teaching website came about through a creative partnership between the British Council (BC), the British Broadcasting Corporation (BBC), China Central Radio and Television University (CCRTVU) and CRTVU-Online Distance Educational Technology Limited (CRTVU-Online) in 2002. As a cooperative endeavor it combines British expertise in English teaching and development of online materials with CCRTVU's knowledge and experience of the English learning environment in China as well as expertise in ICT and development of online materials.

The common ground strategy of the four partners brought about the establishment of the site and this creative partnership has been maintained throughout its development. At its inception many of the website's features were innovative and cutting edge. As a free website it went 
beyond text and made extensive use of flash and multimedia. Since its launch on 5th November 2002 the website has welcomed nearly 10 million unique visitors, visited over 18 million times, from its target audience of business people, English teachers, young professionals and their children throughout China.

During five years of development "in2english.com.cn" has evolved into a highly interactive community. A personalized feature known as "myin2english" helps foster the learners' participation and ventures into the world of mobile learning. This is highlights its continuing commitment to innovation. However, it is also a time to reflect on the lessons learned about Chinese learners' attitude to online learning and also the international cooperation between partners. A retrospective and critical approach is needed to see how far we have come, and how we should proceed in the future.

\section{BACKGROUND OF THE FOUR PARTNERS}

"in2english".com.cn is a joint British-Chinese English language learning project. Collectively known as the Multimedia English Language Learning Initiative (MELLI), four partners have been working together to develop and deliver a comprehensive online English language learning website for China. The parties investing in this unique Britain-China partnership are:

- Cultural \& Education Section, British Embassy - The British Council

- China Central Radio \& Television University - CCRTVU

- BBC World Service - BBC

- CRTVU-Online Educational Technology Limited - CRTVU-Online

\section{The British Council}

The British Council - the Cultural \& Education Section of the British Embassy in China - is well respected for the quality of its English language teaching projects. With "in2english".com.cn, the British Council wants to deliver a quality English language-teaching product that concurrently presents positive aspects of the UK and China in this important Britain-China project.

\section{CCRTVU}

CCRTVU has high brand awareness and a long-standing history in adult education and distance learning. About 2.6 million students currently study through CCRTVU. Most are required to study English as part of their course and some are English majors training to be English teachers, at both primary and secondary level. CCRTVU's experience offers unique access to the market of distance learners and gives the project invaluable physical association with China, ensuring local relevance, and the potential to reach over a million learners directly.

\section{BBC}

$\mathrm{BBC}$ has been teaching English for 60 years, reaching learners that are situated around the globe, in the full range of linguistic markets. Over six decades it has become well known for its radio English learning programs, particularly in China, and more recently is increasingly recognized worldwide for the quality online learning it offers. 
In a market where there is a gap in quality content provision the BBC brand can be maximized as a known and trusted content provider, to communicate a message of quality, reliable content on the web.

\section{CRTVU-Online}

The site is technically supported by a complementary new media service, CRTVU-Online, a joint venture from the established CCRTVU brand and one of China's leading local brand electrical and electronics companies, TCL. CRTVU-Online brings its experience as part of the new era of media delivery in the Chinese educational market to the project. It has a strong commitment to helping China achieve its educational potential. We can see that the four partners have their own strengths with different aims and targets. As partners working on the same project it is essential to find the common ground to benefit all the partners so as to build an English language learning and teaching website for a selected target audience in China.

\section{MEETING THE NEEDS OF THE FOUR PARTNERS}

The different partners clearly have different needs, from public service to commercial, and want to reach different consumers, from teachers to business professionals to the wider ELT market. The challenge facing the cooperation is to make a strategic fit between the different partners and their different needs. In this way, the joint venture would be able to take advantage of all partners. The individual strengths of the partners behind the "in2english".com.cn site, as existing English language teaching and distance-learning providers, offer a synergy of brand strengths.

By analyzing the areas of overlap in the strategic fit of all partners, in conjunction with market data, we were trying to find a clearer set of business aims and objectives for the joint venture, and to define primary and secondary targets. We needed to focus our efforts and activity around the primary targets and also discover what each partner could offer.

Table 1. Analysis of Overlap Areas in the Strategic Fit of All Partners

\begin{tabular}{|l|l|}
\hline The British Council & CCRTVU \\
Aims: & Aims: \\
- Deliver positive, impactful ELT, towards & - Deliver online ELT and training to in-service \\
sustainability within 5 years. & English teachers, as part of distance-learning \\
- Help improve English in all target groups in China, & - Portfolio. \\
particularly primary teachers and teachers training & - Offer quality, open access learning to the wider \\
to teach English in primary schools. & ELT public. \\
- Increase the number of Chinese users learning & - Support short courses, and help students and the \\
English online through excellence and innovation. & wider public achieve their ELT goals in \\
Targets: & certificates/exams. \\
- Primary target: Teachers/teacher training & Targets: \\
Business, young urban professionals and their & - Primary target: Teachers/CCRTVU's teacher \\
children, Influencers and opinion formers. & training. \\
Offer: & - English learners who are studying \\
- Resources, especially ELT resources & vocational/business courses. Wider ELT public. \\
- Finance support & Offer: Legal stakeholder in China ELT experts Office \\
- ELT experts & Network Promotion \\
- Consultancy & \\
- Promotion & \\
\hline
\end{tabular}




\begin{tabular}{|c|c|}
\hline $\begin{array}{l}\text { BBC } \\
\text { Aims: } \\
\text { - Deliver quality English language teaching; } \\
\text { reach a new online education sector in China. } \\
\text { - Refocus and build ELT brand around } \\
\text { "in2english".com.cn, with an innovative new } \\
\text { media product portfolio for China. } \\
\text { - Associate BBC public service/education brand } \\
\text { with online; and explore cost recovery program } \\
\text { of product development, towards a longer term } \\
\text { commercial aim. } \\
\text { Targets: } \\
\text { - Primary target: Cosmopolitans and the } \\
\text { business sector. } \\
\text { - Aspirants, younger urban professional groups } \\
\text { and the wider ELT public (including teachers). } \\
\text { - Opinion formers, influencers, business leaders } \\
\text { and trendsetters. } \\
\text { Offer: } \\
\text { - Resources, especially business and lifestyle } \\
\text { resources. } \\
\text { - Site production experts } \\
\text { - Consultancy }\end{array}$ & $\begin{array}{l}\text { CRTVU-Online } \\
\text { Aims: } \\
\text { - Support their association with Chinese educational } \\
\text { - Build the braning ventures, to deliver quality ELT. } \\
\text { - Develop new online/offline products and support } \\
\text { materials, towards revenue generation. } \\
\text { - Work with international partners and develop } \\
\text { strategic global alliances. } \\
\text { Targets: } \\
\text { Primary target: } \\
\text { - Business and younger urban professional groups. } \\
\text { - Teachers/teacher training in line with CCRTVU } \\
\text { Aims: } \\
\text { - Wider ELT public, including consumers of their } \\
\text { electrics and electronics brand in China. } \\
\text { Offer: } \\
\text { - Site design, update and maintenance } \\
\text { - Technical support in China } \\
\text { - Resources management } \\
\text { - Promotion }\end{array}$ \\
\hline \multicolumn{2}{|c|}{$\begin{array}{l}\text { Strategic fit } \\
\text { Key aims: } \\
\text { - Deliver quality, innovative ELT to key target groups in China. } \\
\text { - Strengthen brand values and secure market share. } \\
\text { - Introduce course-based, structured learning to help learner achieve goals. } \\
\text { - Develop existing and new online product portfolio. } \\
\text { Primary targets: } \\
\text { - Support teachers and teacher training for primary education. } \\
\text { - Reach business sector and professionals in key sectors. } \\
\text { Secondary targets: } \\
\text { - Younger urban professionals and wider ELT public. } \\
\text { - Kids of the above professional groups. } \\
\text { - Communicate with a tertiary target group of influencers, opinion formers and business trend-setters. }\end{array}$} \\
\hline
\end{tabular}

\section{Core Business Objectives}

The redefined joint aims of the project are the following core business objectives: loyalty program, reaching teachers program and evaluation.

Loyalty program - Invest in the "in2english".com.cn online brand, develop the open access site, introduce learning paths, strengthen brand values and secure market share in key target consumer groups of business and teaching professionals. Reaching teachers program - Work closer with key partners, introduce learning paths for primary teachers in conjunction with partner needs and activities. Evaluate - Monitor activity, measure achievements and feedback into site content, business and product development, and communications initiatives. 


\section{Core Business Targets}

Focusing our limited resources, we must drill down to identify and define our target end consumer groups, within key professional sectors, further develop our product proposition in line with market and partner needs, and tailor our message to reach each target group. In order to move forward together, we needed to agree on our objectives and targets. And, we should agree that we would focus our efforts and activity around the primary targets.

After analyzing the differing needs of the different partners, from public service to commercial and their different potential customers from teachers to business professionals, an area of overlap was found. It was in this area of overlap that "in2english".com.cn would operate.

\section{MAKING THE MOST OF THE FOUR PARTNERS AND MEETING THE USERS' NEEDS BROUGHT THE SITE SUCCESS}

Given sufficient goodwill on all sides, we tried to fit the strategy of the four partners and at the same time take advantage of all partners.

\section{Site Content Architecture}

Having identified our target users, "in2english".com.cn sets out to design each zone according to the specific needs of each group. The two primary targets, teachers and business professionals were supported by two separate zones. The Teaching English zone was targeted to Primary school teachers whose own level of English ranges from lower to upper intermediate. Working English was for business people who are interested in learning English for work and whose level is intermediate and upper intermediate. Another target was young urban professionals and the wider ELT public. The Living English zone was created to cater for this group of people who are interested in learning English to enhance their job prospects, and increase travel and educational opportunities. Finally the children of these key group people had a zone of their own For Your Kids although it was hoped some of the parents would find this a fun learning zone as well. In 2004 a community section was added which has become hugely popular with users. They see this resource as a way of improving their English through communicating with users and editors and people's replies and assistance as a motivation to their English language learning interest. The community grew and became as one big friendly family.

As the website developed, what became increasingly clear was that many desired to pass exams such as IELTS and from 2003 an additional zone English for Tests was added which featured examination practice for IELTS and later for CET 4 and BULATS. The target group language level was intermediate or post-intermediate and the target group members were typically non-English majors at university or college who had achieved Band 4 in English and were recent or soon-to-be university or college graduates.

\section{Innovative and Interactive Content}

At its inception "in2english".com.cn offered many innovative and cutting edge features and to this day user feedback has still stressed their appreciation of the resources of flash exercises. In an analysis of our strengths and weaknesses this ability to deliver rich interactive content 
was one of our major strengths. Another important strength lay in our innovative international partnership with "in2english".com.cn representing a quality brand of English. Other innovative features of the website include: interactive content, personalized learning paths, as well as functionality for users to monitor personal progress and achievements.

The aim of the zones was to offer users a choice of creative and innovative materials appropriate to their interests and needs. The key qualities of the zones can be described as: innovative, creative, engaging, attractive, practical, easy to use and appropriate to the target audience. These features took full advantage of what the web could offer e-learning. The zones are creative and attractive, subjects are dealt in an original fashion and the layout, colours and graphics used are attractive. The zones look professional and serious and were very attractive for serious and motivated users. Taking the Teaching English Zone of "in2english".com.cn as an example, it was set up in order to provide innovative and creative multimedia English Language Teaching support to a target audience of Chinese teachers of primary EFL. The target users were very different however. The teachers in this target audience typically posses a low level of English ability and often have little to no formal or recognized training or certification in primary EFL teaching. In addition, primary EFL teachers in many schools in China have very little resources available to them outside a textbook. The Teaching English Zone aimed to provide resources for this group of teachers to coincide with the Basic Requirements for Primary School English outlined by the Ministry of Education in China. It also aimed to provide basic instruction about pedagogy and the EFL profession to support those teachers who were looking to improve their skills and those looking to take the Teaching Knowledge Test or some other recognized initial EFL teaching certification. An underlying aim of the site is one of helping to improve the language level of the regular users of the Teaching Zone.

When considering how engaging the site was this became an important issue. We felt there was a good deal of support to help independent users, such as, glossaries and feedback. There was also a lot of material which would again encourage motivated users. However some users found it difficult to find materials that they wanted to try and so on pages within the various sections we suggested activities that users could try. Another need that cropped up, when the site was up and running was that serious users might like to have records and so yin2english was started as personalized area where users could record their progress in 2004.

\section{Site Promotion}

In 2001, China was successful in its bid to host the 2008 Olympics and in the same year China also became a member of the World Trade Organization. The market became flooded with low Standard English language materials. The challenge was to create quality e-educational content and relevant English language learning materials. Next although the partners all had established ELT credentials it was important to develop loyalty and awareness of the "in2english".com.cn brand. Each of the partners committed themselves to promoting the site in various ways.

The British Council gave press and PR support, including news distribution and media relations, specifically reaching general and educational media. They also encouraged brand 
exposure through tied-in activities around British Council projects that reached teachers and teacher training sectors. When it came to brand exposure the BBC were particularly efficient. They developed 30 to 60 second radio slots of bite-sized quality English language learning content, with an "in2english".com.cn sponsorship line to help expose the brand on BBC's own airwaves. They featured "in2english".com.cn in BBC's Learning English and BBC/BC's joint Teaching English online and offline promotional and educational support materials. Through tied-in activities around BBC projects in China, they reached trade and business sectors, the educational sector, and the wider public with an interest in education and English language learning.

On the Chinese side CCRTVU provided details of useful content and subject areas in their primary teacher training courses to help "in2english".com.cn tailor teaching materials on the site towards specific teaching needs. They introduced some content from "in2english".com.cn into their own courses and course materials to create a cross promotional environment. CCRTVU's TV presenters promoted the site and "in2english".com.cn was presented in their events, conferences, presentations and grass roots activities amongst their target groups, including the wider public. Finally CRTVU-Online's marketing department provided relevant information for a more market-focused product as well as tied-in activities around relevant media relations and publicity events organized by CRTVU-Online, to help expose the brand. They explored the possibilities of reaching beyond the CCRTVU market, to the wider traditional educational market with online access that had an interest in English language learning.

\section{Site Evaluation}

According to the survey and evaluation of the site, "in2english".com.cn has a great success. The followings are the assessment and evaluation statements. The survey by Synovate shows user satisfaction with the Website.

Table 2. Users' Satisfaction of the Website

\begin{tabular}{lccc}
\hline & Earlier Users & Experienced Users & New Users \\
\hline General appearance & $79 \%$ & $81 \%$ & $80 \%$ \\
Website content & $78 \%$ & $86 \%$ & $83 \%$ \\
Content classification of each zone & $76 \%$ & $81 \%$ & $76 \%$ \\
Overall style & $76 \%$ & $80 \%$ & $75 \%$ \\
Font style & $76 \%$ & $71 \%$ & $73 \%$ \\
Font size & $72 \%$ & $71 \%$ & $69 \%$ \\
Color & $72 \%$ & $70 \%$ & $75 \%$ \\
Website structure & $71 \%$ & $82 \%$ & $78 \%$ \\
Title position of each zone & $71 \%$ & $72 \%$ & $69 \%$ \\
Ease of navigation & $67 \%$ & $66 \%$ & $63 \%$ \\
Update speed & $52 \%$ & $64 \%$ & $56 \%$ \\
\hline
\end{tabular}

Kim Ashmore, Manager of LearnEnglish Kids ELT group British Council evaluated Living English zone of the site: The zone goes beyond text and makes extensive use of multimedia there are streaming videos, many sound files, links from the zone to community features. These features (multimedia, community features) take advantage of what the web can offer e- 
learning. The zone makes extensive use of Flash for its activities - the Flash routines look sophisticated and use latest technology. The site is innovative in a field (e-learning) where most free sites offer little more than text and links.

Zhang Shaogang, assistant President of CCRTVU expressed his comments on "in2english" saying:

This is my first experience of working on a Steering Group with international partners and I have been impressed especially by the working practices, for example all the planning and arrangements before meetings, having an agenda, sticking to an agenda at a meeting which makes them more efficient and focused. I think this is a good way of working with partners. In international co-operation, I always use in2english as a reference point as it is our most successful international project. I bring up in2english and use it as the model of success for all types of high level meeting. Also when I negotiate other international projects, for example with French or German partners, I always refer to in2english as the standard or/benchmark for international co-operation.

John Whitehead and Michael Houten from the British Council in London came to "in2english" project team for evaluation and concluded:

"in2english.com.cn" is clearly a very successful project and this is a great tribute to the China team and, in particular, the "in2english" operational team. Partners and users alike acknowledge its quality and effectiveness. It has delivered strongly on the defined objectives and has provided the organization with many useful learning points to contribute towards the development of future e-English learning products.

\section{Users' Stattistics of the Site}

Table 3. Users' Statistics 2003-2007 (from January to July)

\begin{tabular}{|c|c|c|c|c|}
\hline Year & Unique Visitors & \multicolumn{1}{|c|}{ Visits } & Page Views & Media Downloads \\
\hline 2003 & 375,192 & 688,888 & $8,651,381$ & 71,746 \\
\hline 2004 & 569,752 & 975,544 & $3,726,391$ & $1,603,411$ \\
\hline 2005 & $2,490,104$ & $4,405,848$ & $12,237,916$ & $2,330,487$ \\
\hline 2006 & $4,073,211$ & $8,017,454$ & $25,044,918$ & $2,509,595$ \\
\hline 2007 & $1,543,074$ & $4,232,702$ & $18,269,984$ & $1,404,086$ \\
\hline
\end{tabular}

Users' statistics from 2003 to 2007 showed the successful achievement of the program. Therefore, based on "in2english".com.cn, BC establish another two similar sites in Egypt and Mexico copying the same model. Furthermore, many schools and universities use resources of "in2english.com.cn" to go with their courses. In fact four students used "in2english.com.cn" as a successful ELT site to write their dissertation for their master degree. 


\section{DISCUSSION OF PROBLEMS OF SITE DEVELOPMENT AND PARTNERS' COOPERATION}

Although the site proved to be a great success, problems had to be solved on the way to this success both in the establishment and development of the site and the cooperation and communication of the four partners.

\section{Site Update}

Once the site was launched, despite an overall initially good reaction various problems emerged according to the survey we made. The first focus was "who was the site for? "

Generally speaking, the home page design was well received by most adults but some younger people however, gave the impression that they found the site to be somewhat too 'adult'. On the other hand, those who liked the design said that it was suitable for an English teaching website due to its simple design, clarity and clear colour. So the fundamental question became: Is this site for Learners or Teachers? For adults or children? For some people the two pairs of target groups are not easily compatible and this is a problem we will have to address as we move forward. If we have something for everyone does this mean not much real material for anyone in particular? We need to be careful not to do too much with little depth or we risk becoming a jack of all trades and master of none.

The most important way that we tried to address the issues of interactivity was through the setting up of a community zone. This together with the yin2english which had been initiated the year before increased the level of user participation. In fact to begin with there were three communities, teachers, kids and a combined business and living community. It was found that parents were not paying attention to their children while online for security reasons and we removed that option.

In 2005 Learning English was averaging 40 messages a day with the users of the message board posting messages on a variety of topics, from language queries to general chat. However, unfortunately, the Teaching English community averaged only 0-3 messages a day and the feedback from the teachers was that they did not find it particularly rewarding. Therefore it was decided to merge the two into one overall community. This proved a great success and various activities were employed to make it more attractive. For instance the message board was used to ask competition questions with prizes in order to encourage loyalty. Teachers took part in online forums and loyal users were invited to appear in the 'People in the Spotlight' area in the Living English area.

Many users started their own web log, which created debate and interaction between users. A list of top 10, later amended to top 20, users was started, again to encourage loyalty. In short it was found that the site needed to be updated constantly in order to meet the needs of the target groups. 


\section{Site Promotion}

After the establishment of the site, we managed to promote the site mainly through some inhouse activities and conferences with the four partners. But it was not very effective. Later we focused on online promotion, such as online syndication, link exchange and newsletters. Our user figures increased dramatically.

One problem is brand recognition; that the website was a creation of partners did not seem to be very clear to our users. People were aware of the four logos, however they knew little about them and didn't have a clear idea about the role of the four institutions. The BBC was generally recognized but only when users were told about the $B C$ did they reason that this would give the website an authoritative feel, and therefore it must teach authentic English. Young people don't know a lot about CCRTVU and not so many people know CRTVU-Online because it is a newly established company. A clear strategy for promotion of brand recognition must be well planned to achieve the satisfying effects. The result of the survey is stated in Table 4.

Table 4. Brand Recognition Survey Online (275 people were involved)

\begin{tabular}{lcc}
\hline$\quad$ Name of Partners & Number of People & Percentage (\%) \\
\hline BBC & 112 & 41 \\
CRTVU-Online & 74 & 27 \\
CCRTVU & 55 & 21 \\
BC & 34 & 12 \\
\hline
\end{tabular}

\section{Generation of Income}

As a free website which has run for over 5 years, we do hope to generate some income to sustain the maintenance of the site. The VIP section and, later mobile learning, were attempts to make money as the budget for the site was reduced drastically after 2005. Both, unfortunately, had very limited success due to these resources being available free elsewhere and, in the case of the chat room, of being only of interest to those taking IELTS. Another reason is that people still think that face-to-face study is the most effective method of learning English.

\section{Project Management Structure}

When we first started the project, the first problem was how to manage the project in the areas such as site design, resources, research, promotion, personnel, finance and business development. Different partners have different aims and policies and the members of the project team come from different organizations. We solved the problems by having a threelevel of management leading structure: Project Team, Management Group and Steering Group.

- Project Team is responsible for the daily work such as site design and update, resources development, plan for promotion and market.

- Management group is in charge of cooperation with the different departments of the four partners and in trying to solve the problems that occurred in the implementation of the team's work.

- Steering Group makes a decision on the strategy and orientation of the site and also gives approval of important proposals, such as business plans, personnel and finance. 


\section{Partners' Strategy Modification}

The four partners modified their strategy and policy during the five-year cooperation especially the $\mathrm{BBC}$ and $\mathrm{BC}$ in China. The BBC reduced the investment for resources and personnel due to their greater focus on radio program development with Chinese stations in 2005. The BC, who had given important support in finance in the first three years, reduced the investment and involvement of resources and personnel owing to their new establishment of Global English project in 2007.

\section{CONCLUSION}

In conclusion, it is in the common ground of mutual benefits and in the combination of four partners' strengths that "in2english"'s success lies. Partners respect each other and try to solve the problems that occur with equal commitment to cooperation. On the other hand, they sign agreements in detail to state clearly the project strategy, management, budget, personnel, copyright, and so on. In this way all the partners have a healthy and harmonious cooperation and agree on the overall aims of the site whilst keeping the partnership creative and innovative in the interests of developing international cooperation.

\section{BIBLIOGRAPHY}

(Not cited explicitly in the article)

Allum, P. (2004). Evaluation of CALL: initial vocabulary learning. ReCALL, 16 (2), 488-501.

Chou, C. (2003). Interactivity and interactive functions in web-based learning systems: A technical framework for designers. British Journal of Educational Technology, 34 (3), 265-279.

Felix, U. (2004). A multivariate analysis of secondary students' ex perience of web-based language acquisition. ReCALL, 16 (1), 237-249.

Hewer, S. \& L. Shield (2001). Online communities: Interactive oral work at a distance. In T.Atkinson (ed.) Reflections on computers and language learning, London: CILT.

Hughes, J., King, J. T., \& McAvinia, C. (2004). What really makes students like a web site? What are the implications for designing web-based language learning sites? ReCALL, $16(1), 85-102$.

Lam, H. C. (2001). Designing CALL for learning Chinese characters. Journal of Computer Assisted Learning, 17 (1), 115-128.

McInnerney, J. M., \& Roberts, T. S. (2004). Online learning: Social interaction and the creation of a sense of community. Educational Technology \& Society, 7 (3), 73-81.

Picciano, A. G. (2002). Beyond student perceptions: Issues of interaction, presence, and performance in an online Course. Journal of Asynchronous Learning Networks, 6 (1), $21-40$.

Pujola, J.-T. (2002). CALLing for help: Researching language learning strategies using help facilities in a web-based multimedia program. ReCALL, 14 (02), 235-262.

Shaalan, K. F. (2005). An intelligent computer assisted language learning system for arabic learners. Computer Assisted Language Learning, 18 (1-2), 81-109.

Sole, C. R., \& Mardomingo, R. (2004). Trayectorias: A new model for online task-based learning. ReCALL, 16 (1), 145-157. 